УДК $94(410)$

\title{
Е.В. Хахалкина
}

\section{СУЭЦКИЙ КРИЗИС 1956 г. - ПОВОРОТНЫЙ МОМЕНТ БРИТАНСКОЙ ВНЕШНЕЙ ПОЛИТИКИ?}

\begin{abstract}
Суэцкий кризис 1956 г. до сих пор вызывает пристальный интерес отечественных и зарубежных историков. Автор, обращаясь к истории англо-франко-израильской интервенции, выстраивает материал статьи вокруг поиска ответа на вопрос о том, можно ли считать события осени 1956 г. поворотным моментом британской внешней политики. Такая постановка проблемы обусловлена появлением так называемого ревизионистского направления в британской историографии, в рамках которого был представлен новый взгляд на события, связанные с Суэцким кризисом 1956 г.

Ключевые слова: Суэцкий кризис 1956 г.; Великобритания; А. Иден; историография Суэцкого кризиса; Венгерский кризис 1956 г.
\end{abstract}

Суэцкий кризис 1956 г. без преувеличения остается одним из самых заметных международных событий эпохи холодной войны. История кризиса от национализации Суэцкого канала президентом Египта Г.А. Насером до проведения и завершения англофранко-израильской операции, казалось бы, досконально изучена. Открытие в несколько этапов с 1990-х гг. до истечения срока давности архивов Великобритании и других стран наряду с окончанием холодной войны действительно позволило историкам составить всеобъемлющую и более объективную, чем в период острой конфронтации западных стран и СССР, картину событий 1956 г.

Однако в зарубежной, прежде всего британской, историографии по-прежнему дискуссионным остается вопрос о значении Суэцкого кризиса и его влиянии на последующую внешнюю и колониальную политику Великобритании и вектор развития международной политики в указанный период.

В 1990-е гг. были открыты британские архивы, продолжилась публикация американских документов послевоенного времени, в 2003 г. были опубликованы рассекреченные советские документы Архива внешней политики Российской Федерации, относящиеся к ближневосточной политике СССР в 1947-1967 гг. [1].

Эти новые источниковые материалы позволили внести важные уточнения в событийную канву Суэцкого кризиса 1956 г. и предшествующих событий.

В 1952 г. к власти в Египте пришла оппозиция во главе с полковником Г.А. Насером. Лояльная британским властям монархия пала, и была провозглашена республика. Египет, формально никогда не являвшийся британской колонией, входил в сферу интересов Великобритании. Смена режима была воспринята в Лондоне с тревогой.

В 1954 г. с новым египетским руководством Британия заключила договор, в соответствии с которым Великобритания в июне 1956 г. вывела войска из Египта, но база в зоне канала - одна из крупных британских военных баз на Ближнем Востоке - продолжала действовать до истечения срока соглашения, заключенного на 7 лет.

Примечательно, что в меморандуме министра иностранных дел А. Идена, подготовленном еще в конце октября 1952 г., эта база рассматривалась как «хотя и желательная», но «не абсолютно необходимая». Од- нако, исходя из вопросов снижения расходов по быстрой ликвидации базы, было решено оставить в соглашении 1954 г. пункт о сохранении базы до 1961 г. [2. Р. 118].

К началу июня 1956 г. чиновники из министерства финансов, Форин оффис и министерства обороны подготовили меморандум, в котором ставилась задача снижения международных обязательств Британии в связи с уменьшением экономического потенциала и финансовыми трудностями страны [Ibid. P. 61].

Еще в начале 1956 г. канцлер казначейства Г. Макмиллан докладывал, что золотые и долларовые резервы страны упали с максимума в 1,078 млн ф. ст. в июне 1954 г. до 757 млн ф. ст. Другая проблема, принявшая хронический характер, была связана с превышением импорта над экспортом [3. Р. 3].

Все эти трудности, выхода из которых в ближайшей перспективе не просматривалось, обусловливали уменьшение внешнеполитических обязательств Британии. Иначе страна ставила под угрозу, считали эксперты, свою способность «играть действенную роль в международных делах» [2. Р. 61]. Интересы Великобритании, как отмечалось в меморандуме трех ведомств, в первую очередь были связаны с интересами Содружества и странами стерлинговой зоны.

Для того чтобы сократить обязательства страны за границей, авторы документа рекомендовали отказаться от британской базы в зоне Суэцкого канала. При этом эксперты признавали, что район Ближнего Востока стал «решающим театром действий в политическом отношении». Руководству страны рекомендовалось развивать невоенные методы поддержания и расширения влияния в регионе, включая техническую помощь и информационные службы, а также совершенствование британских разведслужб [Ibid. P. 71, 74].

Тем временем молодая египетская республика в лице президента Г.А. Насера ставила задачи по созданию сильной боеспособной армии (25\% бюджета страны стали составлять военные расходы), необходимой для отражения возможной израильской агрессии. Летом 1954 г. было достигнуто соглашение с Соединенными Штатами о поставках оружия Египту, но в начале февраля 1955 г. произошло первое крупное нападение Израиля на Египет в районе Сектора Газа. Нападению подверглись казармы египетских частей, расквартированных в этом палестинском городе, по- 
павшем после перемирия 1949 г. под административное управление Египта. В результате рейда было убито несколько десятков египетских солдат и офицеров, много мирных жителей. Тель-Авив продемонстрировал, что Каир ничего не может противопоставить нападающей стороне из-за отсутствия современного оружия [4. С. 263].

Насеру срочно потребовалось вооружение в большем объеме на случай войны с Израилем. Американское правительство выдвинуло условия, неприемлемые для египетского руководства, в частности США требовали оплату за оружие только в наличных долларах, которыми Египет в достаточной сумме не располагал [5. Р. 229].

В начале марта 1955 г. А. Иден изложил свои впечатления от посещения столиц ближневосточных стран по пути на конференцию участников Манильского договора в Бангкоке. По итогам визита в Каир он пришел к мнению, что недавний инцидент в Газе делает сближение Египта и Израиля пока невозможным [6. Р. 3]. В течение апреля - сентября 1955 г. вооруженные конфликты на границе в районе Газы следовали непрерывно одно за другим.

Крупное нападение израильских войск на египетскую территорию было также совершено в ночь с 1 на 2 ноября 1955 г., в результате которого египетская сторона потеряла 50 человек убитыми и 40 ранеными. На очередное обращение представителей $\mathrm{OOH}$ вывести войска из захваченного района и не мешать специальной комиссии ООН в ее деятельности по нормализации обстановки на этом участке линии египетскоизраильского разграничения Тель-Авив ответил категорическим отказом [7. С. 86].

В этих условиях Г.А. Насер обратился с просьбой о продаже оружия к Советскому Союзу, которого привлекала возможность усилить свое влияние на Ближнем Востоке. Перед тем как предпринять этот шаг, президент Египта несколько раз безуспешно обращался к правительствам США и Великобритании за помощью в решении этого вопроса [8. Р. 654-655].

Советско-египетское сближение началось в 1953 г. В конце 1953 - начале 1954 г. Каир направил в СССР и некоторые страны народной демократии экономическую делегацию во главе с заместителем военного министра генералом Рагабом. Во время пребывания делегации в Москве советское руководство выразило готовность оказать Египту помощь в области строительства промышленных предприятий и ирригационных систем [1. С. 304-305].

Летом 1954 г. Москва и Каир обсудили вопрос об оказании Советским Союзом финансовой и технической помощи Египту в строительстве крупной ирригационной системы в районе Асуана на сумму свыше 1 млрд инвалютных рублей.

Однако когда советская сторона заявила о необходимости предварительного ознакомления советских специалистов с объектом работ на месте, египетское правительство уклонилось от предоставления разрешения на эти мероприятия [Там же. С. 305].

26 июля 1956 г. на митинге в Александрии, посвященном четвертой годовщине свергнувшей монар- хию революции, президент Египта Г.А. Насер объявил о национализации Всеобщей компании морского Суэцкого канала. Эта кампания находилась в англофранцузском владении и получала основные доходы от Суэцкого канала. Эти доходы, по оценкам президента Насера, были равны 34 млн египетских фунтов в год (из которых Египет получал не более 1 млн ф. ст.) и составляли почти $10 \%$ оценочной стоимости масштабной программы строительства плотины на Ниле [9. С. 4-6].

С осуществлением масштабного Асуанского проекта Г.А. Насер связывал развитие промышленности и сельского хозяйства в стране. Строительство на реке Нил выше г. Асуан высотной плотины с мощной гидроэлектростанцией и создание разветвленной оросительной системы могли позволить Египту увеличить площадь культивируемых земель до 800 тыс. га и наладить производство электроэнергии для промышленных предприятий. Значение проекта для Египта было очень велико, но финансировать его самостоятельно Каир не имел экономических возможностей.

Еще в конце 1955 г. свою помощь в осуществлении Асуанского проекта предложили США и Великобритания. Стоимость строительства плотины оценивалась в 1,4 млрд долл., включая 400 млн в твердой валюте, из которых Международный Банк Реконструкции и Развития (МБРР) должен был выделить 200 млн, США и Великобритания - соответственно 56 и 14 млн сразу, а остальные 130 млн позднее [10. Р. 145].

Однако по мере сближения Египта с Советским Союзом, особенно на фоне обозначившегося в 1955 г. военного сотрудничества, эта помощь стала обусловливаться разными оговорками и условиями, приведшими к отказу Лондона и Вашингтона спонсировать египетский проект.

В отказе Британии от помощи Насера, кроме политических причин, важную роль играли экономические факторы. Правительственные эксперты сомневались в способности Каира вернуть огромный заем, предоставить который стесненная в средствах страна была готова только в обмен на лояльность насеровского режима, рассчитывать на которую в сложившихся условиях не приходилось.

Определённую роль сыграли также слухи о финансировании строительства плотины Москвой [11. Р. 141-142]. Глава ЦРУ США А. Даллес озвучил не соответствующую действительности информацию о том, что глава советского МИДа Д.Т. Шепилов во время своего ближневосточного турне предложил Египту помощь в виде беспроцентного займа в 400 млн долл. при аннулировании долга за военные поставки. Запущенная дезинформация «преследовала цель распространить блоковую конфронтацию на ближневосточный регион» и пресечь попытки Насера использовать противостояние двух сверхдержав в собственных интересах [12. С. 365].

Немаловажным был и тот факт, что «хлопковое лобби» в Сенате было против расширения Египтом посевных площадей для выращивания хлопка. Решение Насера установить дипломатические отношения с КНР, возможно, также сыграло определенную роль в отказе США финансировать проект [13. С. 22-24]. 
Как следствие, США, а вслед за ними Великобритания и МБРР, аннулировали свое согласие на оказание финансовой поддержки Египту.

От Советского Союза каких-либо официальных предложений египетскому правительству по оказанию финансовой помощи, как показывают документы, не поступало. В телеграмме в Министерство иностранных дел СССР советский посол в Египте Е.Д. Киселев в мае 1956 г. сообщал, что «Насер... очень хотел получить помощь СССР в деле индустриализации страны» [1. С. 414-416].

Советское правительство инструктировало посла, что в случае, если Г.А. Насер затронет этот вопрос, следует высказать мысль о несвоевременности Асуанского проекта «ввиду дороговизны, а также в связи с тем, что экономическое развитие Египта в настоящее время требует разрешения других неотложных задач по индустриализации страны» [Там же. С. 452-453].

Не получив помощь ни от западных стран, ни от СССР, египетский лидер решил опереться на свои силы.

В выступлении египетский лидер подчеркнул, что Всеобщая компания Суэцкого канала, являющаяся своеобразным «государством в государстве», переходит под непосредственное управление египетского правительства, как и ее доходы, на которые Египет собирается осуществлять Асуанский проект.

Г.А. Насер обосновал свой шаг тем, что Суэцкий канал находится внутри территории страны, и что пришло время «провозгласить египетскую “Декларацию независимости от империализма”» [14. С. 29-32]. Такая позиция свидетельствовала о сложности и неоднозначности происходящих событий. Национализация канала затрагивала не только непосредственно интересы Египта, Британии, Франции и других пользователей канала: она символизировала происходящее изменение соотношения сил в регионе в пользу набиравших силу ближневосточных государств.

Экономический фактор, безусловно, не был определяющим в решении Насера национализировать Всеобщую компанию Суэцкого канала. Для Насера национализация была ответным политическим шагом на отказ западных держав финансировать проект, который для Насера имел существенное значение как «символ свободного процветающего будущего в умах египтян, в то время как западное владение Суэцким каналом было символом колониализма» [15. Р. 555].

С юридической точки зрения национализация канала не была нарушением международных норм. Канал проходил по территории Египта и принадлежал египетскому правительству, о чем говорилось в англоегипетских договорах от 1936 и 1954 гг., по которым Британия признавала, что Суэцкий канал является «нераздельной» и «неотъемлемой» частью Египта [16. C. 3-13, 62, 91-92].

Реакция Великобритании на решение Насера была очень бурной. Консерваторы осудили акт египетского президента, считая его действия несовместимыми с договором о концессии 1854 г. и Константинопольской конвенцией о свободе мореплавания 1888 г.

Для изучения сложившейся ситуации в рамках кабинета министров был создан Комитет по Суэцкому каналу. Уже на следующей день после объявления национализации Комитет изложил свои оценки возможных действий Британии в отношении Египта. В подготовленном документе содержались размышления британских чиновников о мерах давления на Египет. Блокирование египетских стерлинговых счетов, считали авторы меморандума, не нанесет значительного экономического ущерба стране, учитывая, что Каир будет получать доходы от продажи хлопка странам Советского блока. При этом признавалось, что «египтяне не уступят только под экономическим нажимом», следовательно, «на них должно было быть оказано максимальное политическое давление» [2. Р. 165-166].

С этой целью «для защиты интересов Компании Суэцкого канала и обеспечения свободы судоходства по каналу» предполагалось представить дело «на более широкой международной основе», выдвинув в качестве аргументов положения, что «канал представляет жизненно важную связь между Востоком и Западом и его важность как международного водного пути признана в Конвенции 1888 г.» [Ibid. P. 166].

Таким образом, к решению Суэцкого вопроса планировалось привлечь заинтересованные в судоходстве по каналу страны и мировую общественность, которых Британия собиралась убедить в наличии угрозы свободному судоходству по каналу и в необходимости его возвращения под международный контроль. В качестве последнего средства давления на Египет авторы доклада допускали использование силы [Ibid. P. 166]. Такое намерение отражали высказывания как самого премьер-министра А. Идена в тот период, так и членов так называемой Суэцкой группы.

Во главе Суэцкой группы, сложившейся в парламенте в 1952-1953 гг. и насчитывающей к 1956 г. около 100 человек из 345 членов фракции консерваторов в Палате общин, стоял видный парламентский деятель консервативной партии капитан Ч. Уотерхауз [17. Р. 247]. Кроме того, членами группы состояли такие заметные политические деятели, как Дж. Эмери, Г. Макмиллан, лорд Солсбери, Э. Фелл, Дж. БиггсДэвисон, Э. Мод, Р. Черчилль [18. С. 201, 315].

Суэцкой группе противостояла численно меньшая группировка (около 30 чел.), придерживавшаяся позиции так называемого современного консерватизма, или антисуэцкая группа. По мнению ее сторонников, Британия должна считаться с реальной обстановкой и признать, что в англо-американском союзе она может играть только подчиненную роль «младшего партнера». Среди «современных» или «молодых» консерваторов особенно выделялись вторая после премьерминистра фигура в правительстве Р. Батлер, заместитель министра финансов Э. Бойл, заместитель министра иностранных дел А. Наттинг, бывший генеральный прокурор А. Нилд и др. [19. Р. 639].

А. Иден, выступая в Палате общин на следующий день после национализации, сделал заявление, в котором осудил действия Насера как нарушающие судоходство по каналу и права пользователей каналом, в котором заинтересованы многие государства. При этом премьер-министр отметил, что «ситуация долж- 
на быть урегулирована с осторожностью...» [5. Р. 236]. Глава правительства, видимо, осознавал всю сложность и важность возникшего вопроса для его политической карьеры в условиях сильного давления членов Суэцкой группы.

Лейбористы и либералы также осудили национализацию Компании Суэцкого канала. Лидер лейбористкой партии Х. Гейтскелл был «глубоко потрясен своевольным и абсолютно не имеющим оправдания шагом египетского правительства», заявив 2 августа, что «Насер стремится создать Арабскую империю от Атлантики до Персидского залива...». К. Дэвис, лидер либеральной партии, описал национализацию канала как «прискорбный акт» [Ibid. P. 234-237].

Вслед за национализацией последовал этап дипломатического урегулирования возникшей ситуации. Были созваны две конференции, проходившие в Лондоне в августе и сентябре 1956 г. Однако Британию и Францию не устроил результат этих конференций, предлагавший компромисс и фактическое признание национализации юридически законным действием. Лондон уже в начале августа взял курс на подготовку военной операции, о чем предупреждал Вашингтон, рассчитывая на его поддержку.

Однако Белый дом такую поддержку оказать не мог: в начале ноября 1956 г. в США должны были состояться президентские выборы, и Д. Эйзенхауэр не мог рисковать, позволив втянуть себя в военную кампанию европейских стран.

А. Иден, за плечами которого была многолетняя дипломатическая школа, и который по праву считался специалистом по Ближнему Востоку, не был авантюристом, склонным решать международные проблемы силовым путем. И Насера он в реальности не рассматривал как второго Гитлера, но усматривал в нем угрозу политике Великобритании в регионе Ближнего и Среднего Востока, полагая, что если действовать быстро и решительно, то свержение Г.А. Насера и замена его режимом, менее враждебным Западу, не будет трудной задачей.

В начале осени 1956 г. сложилась трёхсторонняя коалиция Великобритании, Франции и Израиля, начавшая готовить военную операцию. На заседании британского кабинета министров в конце октября 1956 г. обсуждались детали военной операции англофранко-израильских сил. Израилю отводилась роль агрессора, что сначала негативно было воспринято израильским премьер-министром. Великобритания и Франция должны были, согласно плану, выступить в роли защитников свободы судоходства по Суэцкому каналу после начала египетско-израильских военных действий. С этой точки зрения, считал премьерминистр А. Иден, интервенция англо-французских войск в зону канала будет принята общественным мнением.

В случае начала полномасштабной военной операции Израиля против Египта Лондон и Париж должны были призвать стороны прекратить наступление и отвести свои войска на 10 миль от Суэцкого канала. Если в течение 12 часов одно или оба правительства (Египет и Израиль) откажутся принять эти условия, британские и французские вооруженные силы должны были быть введены в зону канала для того, чтобы заставить воюющие стороны принять требования западных держав. Престиж «полковника Насера» в случае принятия этих требований, как рассчитывали британские политики, будет фатально подорван. Если же Египет требования не примет, в чем были уверены в Лондоне и Париже, англо-французская военная операция с целью охраны Суэцкого канала будет оправдана.

На первый взгляд, план казался безупречным, но имел некоторые недостатки, которые сыграют негативную роль в исходе операции для союзников по тройственной агрессии. Во-первых, союз Великобритании, Франции и Израиля изначально характеризовался непрочностью в силу не только взаимного недоверия Великобритании и Израиля, но и в силу того, что стороны (Лондон и Париж - с одной стороны, и Тель-Авив - с другой) преследовали по существу разные цели. Тель-Авив стремился главным образом к территориальным изменениям в регионе, европейские союзники - к ликвидации режима Насера и возвращения канала под международное управление. Во-вторых, стороны рассчитывали если не на поддержку, то хотя бы на благожелательный нейтралитет США [20. С. 136], не учитывая важности для последних в условиях предстоящих выборов следования политической платформе, построенной на стремлении к миру.

Ход и результаты операции оказались прямо противоположными задачам участников.

Разработанная в Севре операция преследовала две основные цели. Во-первых, израильские войска должны были в кратчайший срок достигнуть Суэцкого канала, создав угрозу свободному судоходству по нему и тем самым дать повод для вторжения британских и французских сил. Во-вторых, захватив южную часть Синайского полуострова, острова Тиран и Синнафир, они должны были установить контроль над Акабским и Суэцким заливами. Осуществить эту операцию предполагалось за 7-8 суток. Англо-французские войска, в свою очередь, должны были захватить зону канала и Каир.

Однако на деле операция стала развиваться вопреки плану.

30 октября Великобритания и Франция направили ультиматум одновременно Израилю и жертве нападения - Египту. Требования сводились к тому, чтобы войска обеих сторон прекратили в течение 12 часов военные действия на суше, в море и в воздухе и отошли на 10 миль (16 км) к востоку от Суэцкого канала, также от Египта требовали предоставления англофранцузским войскам ключевых позиций в ПортСаиде, Исмаилии и Суэце. В случае отказа две западные державы угрожали военным вторжением в страну с целью защиты свободы судоходства по Суэцкому каналу и разведения двух воюющих сторон, ссылаясь на условия англо-египетского договора 1954 г.

В ответ на нападение двух западных стран и Израиля на Египет Иордания, Сирия и Саудовская Аравия разорвали дипломатические отношения с Великобританией и Францией. 1 ноября египетское правительство приняло аналогичное решение, изучая вопрос о 
выходе из ООН в связи с тем, что «стало очевидно банкротство этой международной организации» [1. С. 541].

Иордания запретила Великобритании использовать военные базы на своей территории и вместе с Сирией объявила о готовности оказать Египту непосредственную поддержку в соответствии с заключенным в Египте в октябре 1956 г. военным соглашением о создании объединенного командования.

Военная операция англо-французских сил в первые дни ее проведения ограничилась воздушными атаками на египетские города и военные объекты и позволила нападающим сторонам завоевать господство в воздухе. 3 и 4 ноября авиация союзников неоднократно совершала налеты не только на военные объекты, но и на жилые кварталы. Из строя была выведена радиостанция «Голос арабов» в Каире, разрушено здание телеграфа в Александрии. Значительный ущерб был причинен таким густонаселенным городам, как Суэц, Исмаилия и особенно Порт-Саид. В Суэцком заливе британский крейсер потопил египетский фрегат «Акка». Движение по Суэцкому каналу было прервано [21. С. 32-34].

2 ноября 1956 г. чрезвычайная сессия Генассамблеи ООН рассмотрела две резолюции. Первая была предложена Канадой и предполагала разработку в течение 48 часов плана для оформления военных сил ООН с целью руководства и обеспечения прекращения вооруженных действий в зоне Суэцкого канала. Вторая резолюция была внесена группой афроазиатских стран во главе с Индией и призывала к немедленному прекращению огня в течение 12 часов. Эта резолюция была принята 64 голосами против 5, 3 из которых были участники тройственной агрессии и «старые» члены Содружества - Австралия и Новая Зеландия [16. С. 163-164].

Немаловажно, что Суэцкий кризис совпал с Венгерскими событиями. В международной обстановке со временем Суэцкого кризиса совпали события в Венгрии, где в сентябре-октябре 1956 г. была предпринята попытка ослабить жесткий контроль со стороны Советского Союза над развитием страны. В конце октября в Венгрии прошли многотысячные демонстрации с требованием демократических свобод. Предпринятое Москвой 24 октября силовое вмешательство в эти события вызвало жесткое сопротивление Венгрии и заставляло искать другие формы налаживания диалога с этой страной «народной демократии». Одной из таких форм стала «Декларация об основах развития и дальнейшего укрепления дружбы и сотрудничества между Советским Союзом и другими социалистическими государствами», принятая на заседании Президиума ЦК КПСС 30 октября. В Декларации признавалась необходимость большего равноправия и обсуждения спорных вопросов, что, по мнению А.С. Стыкалина, не было только тактическим ходом [22. С. 517-518]. Советское руководство осознавало необходимость отхода от прежнего политического курса по отношению к восточноевропейским странам.

По мнению венгерского историка Л. Контлера, обретение Будапештом независимости во внутренней политике при сохранении тесного сотрудничества с
СССР представлялось вполне вероятным, но «эта возможность стала исчезать по мере радикализации революции и, кроме того, международное положение оказалось очень благоприятным для демонстрации СССР военной силы» [23. С. 557].

Этот двойной кризис привел к тому, что впервые в условиях холодной войны Вашингтон и Москва оказались на одной стороне. Советский Союз поддержал резолюции США по осуждению тройственной агрессии против Египта, в свою очередь, США на первоначальном этапе отказались поддержать резолюцию, предложенную новым лидером Венгрии И. Надем и осуждавшую действия СССР в Венгрии [24. С. 227].

Советское руководство располагало информацией из Лондона и Вашингтона, что Запад не будет предпринимать попыток вмешаться в дела Венгрии [25. P. 122]. Хотя 3 ноября американская делегация внесла резолюцию, осуждавшую действия Москвы в Венгрии, советская делегация воспользовалась правом вето. В результате ввода войск в Будапешт 4 ноября 1956 г. и подавления антисоветских выступлений населения попытка Венгрии выйти из орбиты влияния Советского Союза закончилась провалом.

У президента США предпринятая военная акция на фоне событий в Венгрии вызывала особо негативную реакцию, поскольку англо-франко-израильское нападение отвлекало внимание от венгерских событий, которыми в другой ситуации западные державы не преминули бы воспользоваться в пропагандистском плане.

Двойной кризис привел к тому, что заинтересованным сторонам не удалось в полной мере использовать трудности противников в своих интересах.

Впервые в истории СССР и США оказались на одной стороне против колониальных держав, осудив в $\mathrm{OOH}$ действия Лондона, Парижа и Израиля.

Жесткое сопротивление Москвы и Вашингтона привело к тому, что 5 ноября сначала Лондон, а вслед за ним и другие участники прекратили операцию.

На решение Великобритании прекратить военные действия оказали влияние многие факторы. Вопервых, враждебная позиция США и их экономическое давление на страну, которая была на грани девальвации фунта стерлингов. Во-вторых, очевидное распределение сил на международной арене не в пользу агрессоров при активной поддержке Египта со стороны СССР и других арабских и азиатских стран. В-третьих, внутренние разногласия в кабинете А. Идена, где к 6 ноября расклад сил был таков, что вчерашние сторонники военных действий против Египта стали высказываться в пользу прекращения огня и завершения военной операции, политический провал которой был очевиден [10. Р. 171-173].

Для Лондона и Парижа затяжная военная компания была нежелательна с самого начала планирования операции против Египта. С политической точки зрения имела шансы на успех быстрая военная операция, которая бы не оставила времени для дипломатических маневров поддерживающих египетскую республику стран.

22 декабря закончился начавшийся в начале декабря вывод англо-французских войск из Порт-Саида. 
В начале марта 1957 г. Израиль вывел войска с египетской территории.

В экономическом отношении Суэцкая кампания дорого обошлась европейским союзникам. Прямые военные расходы Великобритании на операцию в Египте, по официальным данным, составили не менее 50 млн ф. ст. Суэцкий канал был поврежден и блокирован на шесть месяцев. Взрыв британских нефтепроводов в Сирии и Ливане поставил под угрозу снабжение европейских стран нефтью из ближневосточного региона [1. С. 557].

Европейские союзники не сумели достичь поставленных целей. Вместо свержения Г.А. Насера и замены его лояльным прозападно настроенным лидером результатом военной акции стало усиление авторитета египетского лидера в арабском мире и развивающихся странах Азии и Африки.

Израиль ставил перед собой прежде всего цели военного характера - ослабление военного потенциала Египта и уничтожение баз палестинцев на Синайском полуострове и был заинтересован если не в свержении Насера, то в поражении Египта. При таком развитии событий Тель-Авив мог получить возможность заключить договор с египетским правительством на выгодных для себя условиях. По итогам операции Израиль получил возможность судоходства в заливе Акаба, но не достиг реализации всех поставленных целей [18. С. 345].

Британский премьер-министр рассчитывал, что Суэцкая операция будет быстрой и успешной, а США займут благожелательную, или, в крайнем случае, нейтральную позицию [20. С. 136]. Нейтралитет США был возможен при других обстоятельствах. Канун президентской гонки в США, когда Д. Эйзенхауэр рассчитывал на переизбрание и потому был особенно обеспокоен наличием благоприятной внешнеполитической обстановки, безусловно, не был удачным временем для такого рода операций ближайшими союзниками Вашингтона. Соединенные Штаты не отбрасывали саму возможность военной операции против Египта, но, судя по маневрам даллесовской дипломатии в месяцы, предшествующие нападению на Египет, США могли поддержать силовой вариант не раньше середины ноября.

Не случайно А. Иден и другие британские политики после Суэцкого поражения высказывали мысль о том, что одна из причин неудачи операции - отсутствие поддержки со стороны США в Суэцком вопросе. Британское руководство полагало, что у Вашингтона с Лондоном гораздо больше взаимных интересов и обязательств, чем полагала американская администрация. Даже годы спустя, подчеркивает американский исследователь Р. Хэтэвэй, «Иден так и не понял, что для Соединенных Шатов британская война за Суэц не была американской» [26. Р. 46].

Еще одной из важнейших причин отсутствия поддержки со стороны Соединенных Штатов было также то, для Вашингтона Суэцкий кризис был не соответствующей реалиям времени колониальной войной. Для американской администрации Британия и Франция оставались «узниками своих традиционных коло- ниальных взглядов, так же как и текущих экономических интересов в регионе» [27. Р. 103].

В этих обстоятельствах в среде консерваторов произошел всплеск антиамериканских настроений 127 членов Палаты общин внесли направленный против США проект резолюции. В этом проекте Вашингтон обвинялся в том, что своими действиями «поставил Атлантический союз в крайне опасное положение». 31 октября подал в отставку в знак протеста против «суэцкой политики» заместитель министра иностранных дел А. Наттинг. Однако вотума недоверия правительству Идена удалось избежать [28. С. 224].

Премьер-министр объяснял поражение предпринятой акции недостаточно успешным ошибочным военно-стратегическим планированием, когда главный упор делался на развитие военно-стратегической системы в Европе, и не велась подготовка к крупным десантным операциям [20. С. 137]. Таким образом, Суэцкий кризис продемонстрировал военную неподготовленность Великобритании к проведению таких операций.

Сложившаяся в связи с провалом Суэцкой операции ситуация требовала принятия и осмысления изменившейся роли Британии. На карту в вооруженной акции против Египта правящие круги Уайтхолла поставили не только влияние страны на Ближнем и Среднем Востоке, но и ее престиж на мировой арене.

Для Соединенного Королевства особо острым был вопрос о моральном ущербе ее дипломатии в глазах мирового общественного мнения. Опытная британская дипломатия оказалась оттесненной на задний план США, что также свидетельствовало об определенном кризисе подходов консервативной партии к международным делам и изменении роли Великобритании на глобальном уровне. Все это требовало от руководства страны осмысления сути произошедших после войны изменений и выработки адекватного новым реалиям дня внешнеполитического курса.

Определенный кризис тройственная интервенция против Египта вызвала и в отношениях Великобритании со странами Содружества. Против вооруженного вторжения в Египет выступили новые участники этой организации. Индия, Пакистан и Цейлон подписали совместное заявление об осуждении англо-французской интервенции. По подсчетам, 11\% всех перевозок по Суэцкому каналу приходилось на торговлю Индии, Пакистана, Цейлона и Бирмы. Индийский премьер-министр Дж. Неру 1 ноября направил послания премьер-министру Великобритании Идену и президенту США Эйзенхауэру, в которых содержалось предупреждение, что действия Британии и Франции могут вызвать «громадные последствия» [1. С. 542].

«Старые» члены Содружества наций, такие как Австралия и Новая Зеландия, поддержали Британию в $\mathrm{OOH}$, но эта поддержка носила откровенно вынужденный характер. Первоначально Австралия даже голосовала за принятие резолюции, осуждающей тройственную агрессию. Следует также учитывать, что в результате Второй мировой войны Канада, Австралия, Новая Зеландия стали более тесно связаны с системой обороны 
США. Посредством Тихоокеанского пакта безопасности (создававшего блок АНЗЮС), подписанного в СанФранциско в 1951 г., Австралия и Новая Зеландия были включены в оборонную систему США.

После провала тройственной агрессии обострились британо-французские отношения. Париж изначально не рисковал в Суэцкой операции в той степени, в которой рисковал Лондон. Французские позиции на Ближнем и Среднем Востоке были не так обширны, как у Британии, для Парижа гораздо более значимым был вопрос сохранения влияния страны в Северной Африке. В то же время Париж был крайне недоволен тем, что кабинет Идена принял решение о прекращении военных действий самостоятельно, не посоветовавшись со своим европейским союзником.

Суэцкий кризис стал свидетельством эволюции сложившейся после Второй мировой войны системы международных отношений. Распад мировой колониальной системы и укрепление освободившихся афроазиатских государств как силы, выступающей в качестве субъекта на мировой арене, обусловили трансформацию Ялтинско-Потсдамской системы.

События 1956 г. на Ближнем Востоке и в Восточной Европе показали, с одной стороны, что раздел сфер влияния, определенный на союзнических конференциях в ходе Второй мировой войны, признавался двумя противостоящими мирами, с другой стороны, мир после 1956 г. уже нельзя было характеризовать как биполярный. Суэцкий кризис показал обоснованность претензий стран третьего мира на осуществление самостоятельной политики на международной арене. Движение неприсоединения стало фактором, значимость которого в международной жизни не могли игнорировать участники холодной войны.

Державшиеся в секрете подробности операции стали известны лишь с открытием архивов. С 1990-х гг. исследователи стали осуществлять уже доскональное изучение Суэцкого кризиса от этапа национализации до провала тройственной интервенции.

Несмотря на уже имеющийся широкий пласт литературы, изучение воздействия Суэцкого кризиса на пересмотр внешнеполитического курса Великобритании продолжается.

К полувековой годовщине кризиса обозначилось новое направление в британской историографии, в рамках которого историки-ревизионисты, такие как С. Смит, С. Моби, Н. Эштон и другие, предложили новый взгляд на Суэцкий кризис и деколонизацию. На основе открытых к этому времени архивов историки-ревизионисты выразили мнение о том, что Суэцкий кризис стал не более чем звеном в цепочке неуклонного ослабления британских позиций на Ближнем и Среднем Востоке, и значение событий 1956 г. преувеличено. Так, С. Смит подверг сомнению устоявшийся в научной литературе тезис о стремлении США в 1950-е гг. вытолкнуть Великобританию с территорий Ближнего и Среднего Востока и занять ее место. В своих работах он аргументированно доказывает, что уход Британии из ближневосточного региона не во всех случаях соответствовал интересам США. С. Смит также подвергает сомнению взгляд на
Суэцкий кризис как начало нового курса в британской внешней политике.

В целом, по мнению названных исследователей, более существенное влияние на позиции Великобритании в ближневосточном регионе имели революция в Ираке 1958 г., революция в Йемене 1962 г. и другие [29-33]. При этом историки-ревизионисты сбрасывают со счетом вопросы психологического воздействия Суэцкого кризиса на политический истэблишмент и население Британии.

Однако с точки зрения психологического воздействия на политический истэблишмент и население страны и широты освещения в мире Суэцкий кризис, безусловно, можно с полным основанием считать рубежным моментом во внешней политике Великобритании.

Суэцкий провал стал символом, отделившим надежды Британии на глобальную роль от реального положения дел. Великобритания без поддержки США оказалась не способна на проведение даже таких локальных операций, какой была задумана тройственная интервенция. Политические элиты страны оказались перед необходимостью признать факт перехода страны на позиции региональной державы.

Спустя пятьдесят лет после кризиса британский журнал «Экономист» опубликовал статью, в которой с высоты прошедших лет был дана оценка последствий Суэцкой операции для Британии. После провала военной акции в стране и за ее пределами заговорили о «суэцком синдроме», суть которого, по словам М. Тэтчер, состояла в том, что руководство страны потеряло веру, что Британия способна на все, и пришла к почти невротическому убеждению, что страна не может делать ничего.

Главным уроком Суэца стало то, что Великобритания уже не могла действовать независимо от США. В отличие от Франции, которая смогла возглавить интеграционный процесс, большинству британских политиков оставалось довольствоваться ролью второй скрипки США [34].

Премьер-министр А. Иден приходил в себя после Суэцкого кризиса в доме британского писателя Я. Флеминга на Ямайке. Любопытно, что первый роман писателя «Казино Ройяль», изданный в 1953 г., не имел большого читательского интереса. Романы, опубликованные после кризиса, вызвали всплеск интереса и символически отражали британское видение сложившейся ситуации и англо-американских отношений. Партнерство героев Флеминга - агента Ми-6 Дж. Бонда и агента ЦРУ Феликса Лейтера - было выстроено в книге как взаимоотношения учтивого, умного и бесконечно находчивого Бонда и богатого, но легковесного Лейтера [35].

После возвращения Идена в страну с Ямайки после Суэцкого кризиса одна из британских газет вышла с саркастическим заголовком: «Премьер-министр навестил Британию». В январе 1957 г. А. Иден подаст в отставку.

Британии действительно пришлось играть роль второй скрипки США, сожалея об утрате глобального могущества и стараясь найти себя в роли ведущей региональной державы. 


\section{ЛИТЕРАТУРА}

1. Ближневосточный конфликт : Из документов архива внешней политики РФ, 1947-1967 гг.: в 2 т. / отв. ред. В.В. Наумкин. М., 2003. Т. 1.

2. BDEE. Series A. Vol. 3. The Conservative Government and the End of Empire. 1951-1957. Part 1. L., 1994.

3. The National Archives (United Kingdom). Cabinet Papers (CAB). CAB 128-30. 24 January 1956.

4. Беляев И.П., Примаков Е.М. Египет: время президента Насера. М., 1981.

5. Churchill R. The Rise and Fall of Sir Anthony Eden. L., 1959.

6. CAB 128-28. 7 March 1955.

7. Внешняя политика стран Ближнего и Среднего Востока. М., 1984.

8. Notle R., Polk W. Toward the Policy for the Middle East // Foreign Affairs. 1958. Vol. 36, № 4. P. $645-658$.

9. Примаков Е.М., Арутюнов Р.А. Поучительный урок. М., 1957.

10. Sked A., Cook C. Post-war Britain. A. Political history. N.Y., 1979.

11. Aster S. Anthony Eden. Introduction by A.J.P. Taylor. N.Y., 1976.

12. Филитов А.М. Д.Т. Шепилов: министр - нонконформист // Известные дипломаты России : министры иностранных дел. ХХ век. М., 2007.

13. Румянцев В.П. Ближневосточная политика США и Великобритании в 1956-1960 гг. Томск, 2010.

14. Насер Г.А. Проблемы египетской революции. Избранные речи и выступления. 1952-1970. М., 1979.

15. Hartmann F. The relations of nations. N.Y., 1957.

16. Суэцкий канал. Сборник документов. М., 1957.

17. Gamble A. The Conservative Nation. N.Y., 1974.

18. Пелипась М.Я. Скованные одной цепью: США и Великобритания на Ближнем и Среднем Востоке в $1945-1956$ гг. Томск, 2003.

19. Scardon Ph.C. A Lesson for Our Times: How America kept Peace in the Hungary-Suez Crisis of 1956. Commemorating an Historic Turning Point in the Cold War. N.Y., 2010.

20. Мемуары Антони Идена // Международная жизнь. 1960. № 5. С. 120-166.

21. Медведко Л.И. К востоку и западу от Суэца : (Закат колониализма и маневры неоколониализма на Арабском Востоке). М., 1980.

22. Стыкалин А.С. Восточная Европа в системе отношений Восток-Запад (1953 - начало 1960-х гг.) // Холодная война. 1945-1963 гг. Историческая ретроспектива : сб. ст. М., 2003.

23. Контлер Л. История Венгрии. Тысячелетие в центре Европы. М., 2002.

24. Гайдук И.В. В лабиринтах холодной войны : СССР и США в ООН, 1945-1965 гг. М., 2012.

25. Johnson P. The Suez war. N.Y., 1957.

26. Hathaway R. M. Great Britain and the United States. Special Relations since World War II. Boston, 1990.

27. Brown S. The faces of power. Constancy and change in United States foreign policy from Truman to Johnson. N.Y., 1968.

28. Красильников А.Н. Внешняя политика Англии и лейбористская партия (1951-1964). М., 1968.

29. Reassessing Suez 1956. New Perspectives on the Crisis and its Aftermath / ed. by S.C. Smith. Aldershot, 2008.

30. Smith S. America in Britain's place?: Anglo-American Relations and the Middle East in the aftermath of the Suez Crisis // Journal of Transatlantic Relations. 2012. Vol. 10, № 3. P. 252-270.

31. Ashton N. Harold Macmillan and the "Golden Days" of Anglo-American Relations Revisited, 1957-1963 // Diplomatic History. 2005. Vol. 29, № 4. September. P. 691-723.

32. Idem. A special relationship sometimes in spite of ourselves: Britain and Jordan, 1957-1973 // The Journal of Imperial and Commonwealth History. 2005. Vol. 33, № 2. May. P. 221-244.

33. Idem. Britain and the Kuwaiti Crisis 1961 // Diplomacy and Statecraf. 1998. Vol. 9, № 1. March. P. 163-181.

34. Economist. The Suez Crisis. An affair to remember. 27 July 2006.

35. Prime Ministers and Politics Timeline. URL: http://www.bbc.co.uk/history/british/pm_and_pol_tl_01.shtml (data accessed: 09.11.2015).

Статья представлена научной редакцией «История» 21 декабря 2015 г.

THE SUEZ CRISIS OF 1956: A TURNING POINT OF THE BRITISH FOREIGN POLICY?

Tomsk State University Journal, 2016, 404, 156-164. DOI: 10.17223/15617793/404/25

Khakhalkina Elena V. Tomsk State University (Tomsk, Russian Federation). E-mail: ekhakhalkina@mail.ru

Keywords: Suez Crisis of 1956; Great Britain; Anthony Eden; historiography of Suez Crisis; Hungary Crisis of 1956.

The Suez Crisis of 1956 still attracts a keen interest of domestic and foreign, especially British, historians. The first decade of the 21 st century noted a surge of monographs and articles devoted to a comprehensive and thorough study of the events of the autumn of 1956. This situation, first of all, refers to Western historiography; however, Russian historical science, responding to the opening of the archives of the United Kingdom and other countries, had new fundamental publications related to the history of the triple AngloFrench-Israeli intervention in 1956. In describing the events of the autumn of 1956, the author also touches upon the Hungarian Crisis that coincided with the triple Anglo-French-Israel intervention and had a significant impact on the discussion of the events in the area of the Suez Canal in the Security Council and the General Assembly of the United Nations. Particular attention is paid to the reaction of the USA and the USSR on the Suez and Hungarian Crises. For the first time during the Cold War, Moscow and Washington were on the same side against the colonial powers and strongly condemned the military action against Egypt. At the same time, the White House could not use unrest in Hungary for propaganda purposes. The author, referring to the history of the events of the summer and autumn of 1956, builds material of the article around a search for an answer to the question of whether it is possible to consider the events of the autumn of 1956 a turning point of the British foreign policy. This formulation of the problem is due to the advent of the so-called revisionist trend in British historiography which presented a new view of events related to the implementation and consequences of the Suez operation against Egypt in 1956. Revisionists deny the Suez Crisis as a line after which the British policy in the Near and Middle East changed dramatically. However, questions remain about the impact of the events of the autumn of 1956 on the colonial policy and other areas of foreign policy of Britain. For the UK, the crisis highlighted the need to rethink the chosen strategy not only in the Middle East, but also in the matters of decolonization, which at the turn of the 1950s and 1960s acquired a prompt character in connection with the strengthening of the so-called "non-aligned movement" and the growth of the Asian and African countries in the UN. The Suez crisis had a clear impact on the political crisis in the country and had an important psychological impact on the perception of the country by the population and by the political elite. In the early 1957, Prime Minister Anthony Eden resigned and H. Macmillan became a new head of government. He put forward new initiatives in the field of colonial and European policy. A new chapter began in British history. 


\section{REFERENCES}

1. Naumkin, V.V. (ed.) (2003) Blizhnevostochnyy konflikt: Iz dokumentov arkhiva vneshney politiki RF, $1947-1967$ gg.: v 2 t. [The Middle East Conflict:. From the Russian foreign policy archive documents of 1947-1967: in 2 vols]. Vol. 1. Moscow: Mezhdunarodnyy fond "Demokratiya".

2. Hyam, R. \& Louis, W.R. (eds) (1994) BDEE. Series A. Vol. 3. The Conservative Government and the End of Empire. 1951-1957. Part 1. London.

3. The National Archives (United Kingdom). Cabinet Papers (CAB). CAB 128-30. 24 January 1956.

4. Belyaev, I.P. \& Primakov, E.M. (1981) Egipet: vremya prezidenta Nasera [Egypt: President Nasser's time]. Moscow: Mysl'.

5. Churchill, R. (1959) The Rise and Fall of Sir Anthony Eden. London: MacGibbon \& Kee.

6. CAB 128-28. 7 March 1955.

7. Ismailova, R. \& Mardek, H. (1984) Vneshnyaya politika stran Blizhnego i Srednego Vostoka [Foreign Policy of the Middle East]. Moscow: Mezhdunarodnye otnosheniya.

8. Notle, R. \& Polk, W. (1958) Toward the Policy for the Middle East. Foreign Affairs. 36:4. pp. 645-658.

9. Primakov, E.M. \& Arutyunov, R.A. (1957) Pouchitel'nyy urok [An instructive lesson]. Moscow: Gospolitizdat.

10. Sked A., Cook C. Post-war Britain. A. Political history. N.Y., 1979.

11. Aster, S. (1976) Anthony Eden. N.Y.: Viking Press.

12. Filitov, A.M. (2007) D.T. Shepilov: ministr - nonkonformist [D.T. Shepilov: Minister - nonconformist]. In: Torkunov, A.V. (ed.) Izvestnye diplomaty Rossii: ministry inostrannykh del. XX vek [Famous Russian diplomats: foreign ministers. 20th century]. Moscow: Moskovskie uchebniki i Kartolitografiya.

13. Rumyantsev, V.P. (2010) Blizhnevostochnaya politika SShA i Velikobritanii v 1956-1960 gg. [US and British Middle East policy in 1956-1960]. Tomsk: Tomsk State University.

14. Naser, G.A. (1979) Problemy egipetskoy revolyutsii. Izbrannye rechi i vystupleniya. 1952-1970 [Problems of the Egyptian revolution. Selected speeches and presentations. 1952-1970]. Moscow: Mezhdunarodnye otnosheniya.

15. Hartmann, F. (1957) The relations of nations. N.Y.: Macmillan.

16. IMO. (1957) Suetskiy kanal. Sbornik dokumentov [The Suez Canal. Collection of documents]. Moscow: IMO.

17. Gamble, A. (1974) The Conservative Nation. London: Routledge and Kegan Paul.

18. Pelipas', M.Ya. (2003) Skovannye odnoy tsep'yu: SShA i Velikobritaniya na Blizhnem i Srednem Vostoke v 1945-1956 gg. [Chained: the United States and Great Britain in the Middle East in 1945-1956]. Tomsk: Tomsk State University.

19. Skardon, Ph.C. (2010) A Lesson for Our Times: How America kept Peace in the Hungary-Suez Crisis of 1956. Commemorating an Historic Turning Point in the Cold War. Bloomigton, Indiana.

20. Mezhdunarodnaya zhizn'. (1960) Memuary Antoni Idena [Memoirs of Anthony Eden]. Mezhdunarodnaya zhizn'. 5. pp. 120-166.

21. Medvedko, L.I. (1980) K vostoku i zapadu ot Suetsa: (Zakat kolonializma i manevry neokolonializma na Arabskom Vostoke) [To the east and west of Suez (Sunset of colonialism and neocolonialism maneuvers in the Arab world) ]. Moscow: Politizdat.

22. Stykalin, A.S. (2003) Vostochnaya Evropa v sisteme otnosheniy Vostok-Zapad (1953 - nachalo 1960-kh gg.) [Eastern Europe in the system of East-West relations (1953 - early 1960s)]. In: Egorova, N.I. \& Chubar'yan, A.O. (eds) Kholodnaya voyna. 1945-1963 gg. Istoricheskaya retrospektiva [Cold War. 1945-1963. A Historical Retrospective]. Moscow: Olma-Press.

23. Kontler, L. (2002) Istoriya Vengrii. Tysyacheletie v tsentre Evropy [History of Hungary. A Millennium in the center of Europe]. Moscow: Ves' mir.

24. Gayduk, I.V. (2012) V labirintakh kholodnoy voyny: SSSR i SShA v OON, 1945-1965 gg. [In the labyrinths of the Cold War: the Soviet Union and the United States in the United Nations, 1945-1965]. Moscow: RAS Institute of World History.

25. Johnson, P. (1957) The Suez war. N.Y.: Greenberg.

26. Hathaway, R.M. (1990) Great Britain and the United States. Special Relations since World War II. Boston, MA: Twayne.

27. Brown, S. (1968) The faces of power. Constancy and change in United States foreign policy from Truman to Johnson. N.Y.: Columbia University Press.

28. Krasil'nikov, A.N. (1968) Vneshnyaya politika Anglii i leyboristskaya partiya (1951-1964) [The foreign policy of England and the Labour Party (1951-1964)]. Moscow: Nauka.

29. Smith, S.C. (ed.) (2008) Reassessing Suez 1956. New Perspectives on the Crisis and its Aftermath. Aldershot: Ashgate Publishing Limited.

30. Smith, S. (2012) America in Britain's place?: Anglo-American Relations and the Middle East in the aftermath of the Suez Crisis. Journal of Transatlantic Relations. 10:3. pp. 252-270.

31. Ashton, N. (2005) Harold Macmillan and the "Golden Days" of Anglo-American Relations Revisited, 1957-1963. Diplomatic History. 29:4. September. pp. 691-723.

32. Ashton, N. (2005) A special relationship sometimes in spite of ourselves: Britain and Jordan, 1957-1973. The Journal of Imperial and Commonwealth History. 33:2. May. pp. 221-244. DOI: 10.1080/03086530500123812

33. Ashton, N. (1998) Britain and the Kuwaiti Crisis 1961. Diplomacy and Statecraft. 9:1. March. pp. 163-181. DOI: 10.1080/09592299808406074

34. The Economist. (2006) The Suez Crisis. An affair to remember. The Economist. 27 July 2006.

35. Prime Ministers and Politics Timeline. [Online]. Available from: http://www.bbc.co.uk/history/british/pm_and_pol_tl_01.shtml. (Accessed: 09 November 2015). 